\title{
Megatrends and Trends Shaping Supply Chain Innovation
}

\author{
Dimitra Kalaitzi, Aristides Matopoulos, Rosanna Fornasiero, \\ Saskia Sardesai, Ana Cristina Barros, Sébastien Balech, \\ and Victoria Muerza
}

\begin{abstract}
Companies operate in a macro-environment that is changing considerably due to large, transformative global forces namely megatrends and trends. The wave of these megatrends and trends generates new prospects as well as challenges for the future of supply chains. This chapter provides a review of 23 major megatrends and 72 trends identified in multiple dimensions along Political, Economic, Social,
\end{abstract}

\section{Kalaitzi $(\varangle) \cdot$ A. Matopoulos}

Department of Engineering Systems \& Supply Chain Management, College of Engineering and Physical Sciences, Aston University, Aston Triangle, Birmingham B4 7ET, UK

e-mail: d.kalaitzi3@aston.ac.uk

\section{R. Fornasiero}

Institute of Intelligent Industrial Technologies and Systems for Advanced Manufacturing, National Council of Research (STIIMA-CNR), Via Alfonso Corti, 12-20133 Milan, Italy

e-mail: rosanna.fornasiero@cnr.it

Institute of Electronics, Computer and Telecommunication Engineering, National Council of Research (IEIIT-CNR), c/o Università di Padova, via Gradenigo 6/B, 35131 Padova, Italy

S. Sardesai

Fraunhofer Institute for Material Flow and Logistics, Joseph-von-Fraunhofer-Str. 2-4, 44137

Dortmund, Germany

e-mail: saskia.sardesai@iml.fraunhofer.de

A. C. Barros

INESCT TEC Institute for Systems and Computer Engineering, Technology and Science, Campus da FEUP, Rua Dr. Roberto Frias, 4200-465 Porto, Portugal

e-mail: ana.c.barros@inesctec.pt

S. Balech

PNO CONSULTANT, Avenue de la Joyeuse Entrée 1, 1040 Brussels, Belgium

e-mail: sebastien.balech@gmail.com

\section{Muerza}

MIT International Logistics Program, Zaragoza Logistics Center, C/Bari 55, Edificio Náyade 5 (PLAZA), 50197 Saragossa, Spain

e-mail: vmuerza@unizar.es

University of Zaragoza, Quantitative Methods for Business and Economy, Gran Vía 2, 50005

Saragossa, Spain 
Technological, Legal, and Environmental (PESTLE) dimensions. The results are based on a systematic literature review and an experts' workshop, and can be used to generate future supply chain scenarios.

Keywords Megatrends · Trends $\cdot$ PESTLE analysis $\cdot$ Logistics $\cdot$ Supply chain management $\cdot$ Supply chain scenarios

\section{Introduction}

Megatrends are "large social, economic, political and technological changes [that] are slow to form, and once in place, they influence us for some time" (Kotler 2002, p. 137). Trends, as an indication into a direction of change, are driven by megatrends. For example, aging population is a megatrend and some of its trends are buying habits, and workforce gaps. Megatrends are observed over decades (15 + years) and affect almost all world regions while trends are observed over 5-10 years on specific parts of the world (Pictet asset management 2017).

Megatrends (e.g. new digital technologies) have a heavy influence on supply chains and they could impact product, process and network configuration (e.g. Calatayud et al. 2019; Birkel and Hartmann 2019). For example, blockchain technology (which is a trend) could lead to transparency, but it could disrupt the structure of supply chains as some intermediaries may have to be removed and the supply chain finance (Wang et al. 2019). Supply chain finance solutions can also be reshaped and boosted by the use of other technological trends e.g. artificial intelligence, internet of things, and big data analytics (Caniato et al. 2019).

Given the presence of these technologies, the role and relevance of supply chain governance mechanisms will be affected; e.g. digital transformation impacts on supply chain collaboration and integration (Barbieri et al. 2019). Companies have to develop a thorough understanding of these changes to avoid unexpected and negative effects and concurrently create opportunities to ensure long term survival. Future scenarios and hypotheses can be developed that will explore about how specific industries might evolve (Gernandt 2012).

There are numerous studies (e.g. Gernandt 2012; Seppälä 2016) that have identified several megatrends and trends such as electric vehicles, efficient multi-modal networks (e.g. Speranza et al. 2018), knowledge based development to talent management (e.g. Bowersox et al. 2000; Stank et al. 2015; Sweeney 2013), additive manufacturing and information systems (Fawcett and Waller 2014; Kemppainen and Vepsäläinen 2003). There is a lack of state of the art and comprehensive review of the list of megatrends and associated trends in the field of supply chain management and logistics. Apart from the studies mentioned above, consulting firms such as EY, PWC and KPMG have explored megatrends by frequently mentioning demographic shifts, geopolitical changes and environmental impacts as key megatrends. These studies lack comprehensive and coherent understanding of megatrends with 
political, economic or social megatrends being the center of attention (Malik and Janowska 2018).

Thus, the motivation of this study is to identify and verify systematically which megatrends are considered the most influential in this field by researchers and professionals. The purpose of this chapter is to recognize and increase knowledge of the megatrends shaping the future of supply chains and provide a comprehensive list of trends that addresses critical dimensions e.g. political, technological, environmental, and others. Through a systematic literature review, the following research questions intend to be answered in this chapter:

$R Q 1:$ "What are the megatrends shaping the future of the supply chains?"

RQ2: "What are the trends that can be derived from these megatrends shaping the future of supply chains?"

From a managerial perspective, this analysis allows companies to build a longterm supply chain strategy that is proactive, rather than reactive, by having a thorough understanding of their current position, but also ensuring they have a plan to respond in complex and dynamic environments and reduce perceived uncertainty. This research further provides theoretical contribution by filling the literature review gap as a comprehensive list of megatrends and trends that will be identified. Researchers can focus on each of the megatrends and its implications and develop supply chain scenarios. Thus, the results of this chapter will be further used in the next chapters as a basis for future scenarios generation. The remainder of this chapter is organized as follows: Sect. 2 outlines the research design; Sect. 3 presents and discusses the findings of the literature review. Section 4 draws conclusions and discusses future research avenues.

\section{Methodology}

A systematic literature review and a workshop with experts serves to identify relevant megatrends and trends for supply chain management. According to Denyer and Tranfield (2009), the systematic literature review process entails five steps: (1) process question formulation, (2) locating literature, (3) study selection and evaluation, (4) analysis and synthesis, and finally (5) reporting and using the results. The steps are described below, apart from the first step as it has been already discussed in the previous sub-section and the final step, i.e. reporting and using of the results, which is presented in the next sub-section.

The search of the studies was conducted from November 2017 to January 2018. The following keywords were used to find the relevant studies: (supply chain management) OR (logistics) OR (manufacturing) OR (transportation) OR (process manufacturing) OR (distribution) AND (future supply chain) OR (next generation supply chains) OR (megatrends) OR (trends).

Relevant journal papers and book chapters were identified by using the search field "Topic" to screen well-known academic databases namely ABI/INFORM Global, Academic Search Premier (EBSCO), Science Direct, Emerald and Google Scholar. 
Our research was not limited to specific areas e.g. "Engineering", "Operations Research Management Science".

Apart from journal papers and book chapters, grey literature that is not controlled by commercial publishers and entails government, academics, business and industry in print and electronic formats supplements the literature review. The grey literature can minimize bias, "increase reviews' comprehensiveness and timeliness, and foster a balanced picture of available evidence" (Paez 2017, p. 233). Grey literature identified by using web searching, particularly the Google search engine was utilized (file type: pdf search filter, as most of the reports, conference papers etc. are in the form of PDFs) or search within certain websites was also followed e.g. PricewaterhouseCoopers, Roland Berger websites to identify information regarding a specific megatrend or trend e.g. resource scarcity, climate change.

The risk of bias was reduced by implementing clear exclusion and inclusion criteria. As our search shall support developments of the future, we only integrated studies from 2010 onwards. The following filters were used to include the most relevant studies: title, abstract and keywords, introduction, conclusion were checked. Duplicate studies were excluded as well as articles or reports that are irrelevant and not written in English, leading to the review of 125 studies. Multiple databases were used, thus the authors contributed with different relevant articles to minimize bias (Kalaitzi et al. 2018a).

The data was synthesized via thematic analysis using the iterative thematic synthesis process and the NVivo software. 'Open coding' was used to identify trends within the 349 studies and thus create the first-order themes, the trends. According to Collis and Hussey (2009, p. 179) "The codes are labels which enable the qualitative data to be separated, compiled and organised". Then the second-order themes were created, which are the megatrends, by connecting the first-order themes. The last step was to link all the related second-order themes under one aggregate dimension, namely Political, Economic, Social, Technological, Legal and Environmental (PESTLE). By utilizing the PESTLE analysis all the external forces/factors in the macro environment can be captured. Managers in the field of supply chain can use these factors to identify where supply chains currently stand and assess their implications on the future development of their business. A similar approach has been applied in other studies e.g. Yudha and Tjahjono (2019) who analyzed renewable energy industries to identify inefficient legislations and support the development of new strategic policies in the fossil fuel industry. Figure 1 describes the PESTLE dimensions and its content as used by Yudha and Tjahjono (2019).

For example, in the political dimension two second-order themes emerged, namely protectionism (first-order themes: import tariffs, quotas, different tax structures) and political stability (first-order themes: terrorism/conflicts). To identify the first-order themes, the following procedure was applied: the authors initiated a data extraction via randomly selecting a sample of studies to keep the data extraction consistency. The final findings were checked for consistency at a meeting that was arranged to discuss and resolve any disagreements.

After the systematic literature review, a workshop with 18 academics and practitioners from the UK, Germany, Italy, Netherlands, Belgium, Spain and Portugal was 
held (see Fig. 2). A mind mapping software supported the discussion to refine and extend the findings of the megatrends and trends gained from the literature review. An expert's workshop is a cost-effective and time efficient method in comparison with

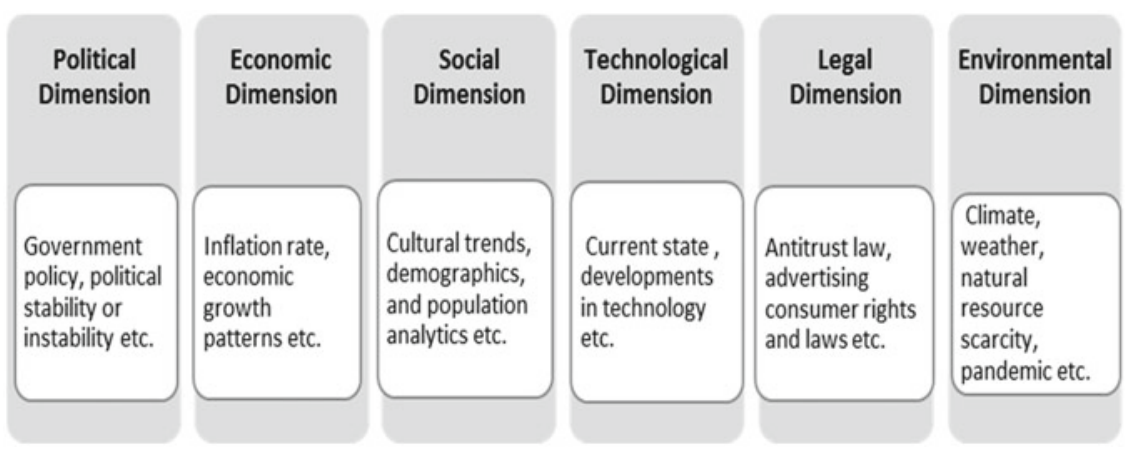

Fig. 1 PESTLE dimensions. Adapted from Yudha and Tjahjono (2019)

Netherlands

Fig. 2 Workshop participants across seven countries 
others such as Delphi research; as the experts gather at the same time and location, it maximizes the compilation of information. It thus leads to richness of information, and enable the experts to participate actively. The workshop participants for the conducted expert workshop are listed in Fig. 2.

\section{PESTLE Analysis}

Based on the thematic analysis of the secondary and primary data, 23 megatrends and 72 trends emerged which are further explored and presented in the below sub-sections based on the aggregate PESTLE dimensions.

\subsection{Political}

One of the most important political changes emerging over the last years is protectionism including several trade policies such as tariffs and import quotas, thus policies that try to protect domestic industries against foreign competition. For example, European Union (EU) duty on imports cars from the United States (US) is 10\%, whereas the US duty on imports from the EU is only $2.5 \%$ (Europa 2015). Another example of protectionism is the US import tariffs of $25 \%$ on steel and $10 \%$ on aluminum. Companies operating in Mexico and China may be affected by increasing import duties and tariffs (PwC 2017). Regarding quotas, China applied those for rare earth elements from 2005 until 2015 until the World Trade Organization forced China to remove the export quotas. Apart from tariffs and quotas, governments offer subsidies (e.g. cheap loans) to local firms so they can compete well against foreign imports (de Kluyver 2010). For example, the EU offers more than $€ 112$ billion per year of fossil fuel subsidies to the transportation industry (Hill 2017). Last but not least, it needs to be highlighted that the total tax share in consumers' prices and taxation systems are not the same across the globe and thus integrate complexity into the supply chain. For instance, different measures to calculate tax are used in Bangladesh, where taxation for tyres is based on retail prices whereas cigarette length is taken into account in India (Shang et al. 2015).

Another megatrend is related to political stability, an indicator of growth, which is crucial for companies. In contrast, political instability (i.e. terrorism/conflicts such as wars, social unrest) can have severe impacts on supply chain operations. For instance, the attack in the twin towers of New York City in September 11, 2001 led Ford, an automotive manufacturer, to shut down five of its plants in the USA and to deficit in land imports exceeding US \$350mln (Bueno-Solano and Cedillo-Campos 2014). Regarding social unrest, all regions face some degree of instability, e.g. as anti-

government demonstrations, riots, and strikes. For example, "labor issues at West Coast container ports disrupted service in 2015 , drove volumes to other ports, and 
Table 1 Political dimension megatrends and trends

\begin{tabular}{|c|c|c|}
\hline Megatrends & Trends & References \\
\hline Protectionism & $\begin{array}{l}\text { Import tariffs, quotas, subsidies } \\
\text { different tax structures }\end{array}$ & $\begin{array}{l}\text { Benjelloun et al. (2009), Boston } \\
\text { Consulting Group (2016), BVL } \\
\text { (2013), Clausen et al. (2014), Deloitte } \\
\text { (2015a), DHL (2013, 2016a, 2017) } \\
\text { Hajkowicz et al. (2016), Deloitte } \\
\text { (2015b), Harrington (2015), Kewill } \\
\text { (2013), PwC (2009), Schuckmann } \\
\text { et al. (2012), SMMT (2015), von der } \\
\text { Gracht and Darkow (2011) }\end{array}$ \\
\hline Political stability & Terrorism/conflict, social unrest & $\begin{array}{l}\text { BVL (2013), Cerasis (2017), DHL } \\
\text { (2012), FTA (2016, 2017), Grant } \\
\text { Thornton (2017), PwC (2011, 2017), } \\
\text { Sana (2017), von der Gracht and } \\
\text { Darkow (2011), World Bank Group } \\
\text { (2017) }\end{array}$ \\
\hline Supranationalism & Trade agreements, free movement & $\begin{array}{l}\text { KPMG (2014, 2017), WEFORUM } \\
\text { (2016), World Economic Forum (2016) }\end{array}$ \\
\hline
\end{tabular}

altered seasonal patterns" (Kearney AT 2016a, p. 18). Finally, the megatrend supranationalism is linked with trade agreements and free movement which determine supply chain decisions (e.g. the number and location of the production facilities, supplier selection). Brexit provides an example for this megatrend with a direct impact on supply chains. Specifically, as trade agreements will be restricted some studies highlight that $32 \%$ of EU suppliers will be substituted by local suppliers and $46 \%$ of EU companies will avoid UK suppliers (McKevitt 2017). Table 1, provides an overview of the megatrends and trends related to the political dimension.

\subsection{Economic}

A key trend that emerged under the economic dimension is economic growth in countries such as China and the MINT (Mexico, Indonesia, Nigeria, and Turkey) results in global trade shift (Francesco and Ardita 2015). It is projected that by 2030, China will be the largest economy in terms of Gross Domestic Product (GDP) while by 2050 India would be the third largest economy in the world. This will influence the demand, and the design of the supply chain networks (PwC 2015). Glocalization is another trend that entails the process of adapting international products to the local culture in which they are sold and also impact supply chain configuration and product structure (Hong and Song 2010). For example, fast-food chains such as McDonald offer their global, iconic brands but at the same time there are local menu options.

Moreover, digital economy trend appeared through the literature where customers use online platforms (e.g. Airbnb, Uber) to facilitate the process of sharing. Sharing 
economy industry meanwhile established a worth of $£ 7$ billion a year (Kleiner Perkins 2017). Peer-to-peer transportation facilitated transactions of $€ 5$ billion in 2015 (PwC 2016a) and it can be applied to inter/ intra- city logistics and movement of goods by ride-sharing or by truck-sharing (DHL 2016a). Regarding the trend from an economy of goods to an economy of services, new selling platform or new, upcoming internet services will be introduced. For example, grocery stores with both virtual and physical presence are introduced by platform providers e.g. by Amazon and Alibaba. Concerning the megatrend financial innovation, there are trends such as cashless payments and digital currencies that aim to improve the security of the financial transactions in the supply chains. Thus, business-to-consumer (B2C) transactions are increasingly digitized (Bons et al. 2012). Last but not least, financial technology (Fintech) firms are expected to revolutionize supply-chain finance. However, FinTech companies face regulatory uncertainty that can act as burden on companies' prospects for growth (Boston Consulting Group 2017).

Thus, under the economic dimension three megatrends and 11 trends emerged (see Table 2).

Table 2 Economic dimension megatrends and trends

\begin{tabular}{|c|c|c|}
\hline Megatrends & Trends & References \\
\hline Global trade shift & $\begin{array}{l}\text { Economic growth in emerging } \\
\text { economies, export growth, } \\
\text { investment, globalization, } \\
\text { glocalization and emergence of } \\
\text { born-global firms }\end{array}$ & $\begin{array}{l}\text { Accenture (2016), Aggelakakis et al. } \\
\text { (2015), ALICE (2013), BVL (2013), } \\
\text { Kearney AT (2014, 2016a), } \\
\text { Boumphrey and Brehmer (2017), } \\
\text { Cerasis (2017), Clausen et al. (2014), } \\
\text { Csiro (2014, 2016), Deloitte (2017), } \\
\text { DHL (2015, 2016a, 2017), } \\
\text { Elmegaard (2016), European Agency } \\
\text { for Safety and Health at Work } \\
\text { (2016), FTA (2016), Gernandt } \\
\text { (2012), Hajkowicz et al. (2016), } \\
\text { Harrington (2015), ITC (2017), } \\
\text { McKinsey Global Institute (2012, } \\
\text { 2016a, 2016b), PwC (2015, 2016b, } \\
\text { 2011), Roland Berger (2014), Sana } \\
\text { (2017), Schuckmann et al. (2012), } \\
\text { SMMT (2015), UNIDO (2013), } \\
\text { UKCES (2014), United Nations } \\
\text { (2010), von der Gracht and Darkow } \\
\text { (2011), World Bank Group (2017) }\end{array}$ \\
\hline Digital economy & $\begin{array}{l}\text { Sharing economy, from an } \\
\text { economy of goods to an } \\
\text { economy of services }\end{array}$ & $\begin{array}{l}\text { Boumphrey and Brehmer (2017), } \\
\text { Grant Thornton (2017) }\end{array}$ \\
\hline Financial Innovation & $\begin{array}{l}\text { Digital currencies, cashless } \\
\text { payment, the financial } \\
\text { technologies (Fintech) } \\
\text { revolution }\end{array}$ & Capgemini (2017), EY (2017) \\
\hline
\end{tabular}




\subsection{Social}

Under the social dimension a key megatrend that identified is population growth. World population is forecasted to reach 8.5 billion by 2030 and the main contributors to this growth will be Africa and Asia followed by Northern America, Latin America and the Caribbean and Oceania (United Nations 2015). Consequently, demand for land and food will grow substantially by 2050 . Another trend considers the ageing population as it projected that $56 \%$ of the total population will be 60 years or over by 2030, mainly in the developed regions (United Nations 2015). This will have an impact on the logistics industry as e.g. the average age of truck drivers has increased more rapidly in comparison with other industries due to the inability of attracting young workers entering the industry (The Conference Board of Canada, 2013). There is a shortage of 59,000 Heavy Goods Vehicle (HGV) drivers in the UK (FTA 2019). Apart from drivers, hiring skilled workers is a big challenge for supply chain managers as there is a shortage of workers with the right skills that delay also the implementation of digital technologies (MHI 2020). However, it is suggested that 35 million people will move from less developed countries to developed ones between 2015 and 2030 (Roland Berger 2017) that will lead to workforce expansion and therefore increasing demand and investment. New megacities and smart cities particularly will grow, and the related needed investments estimated to $\$ 1.8$ trillion by 2030 (OECD 2015). By 2025 it is expected that more than $60 \%$ of the world population will be in urban cities (United Nations 2014).

These trends will lead companies to look for alternative transport modes that suit the urban centers and force them to change their overall distribution strategies with the ultimate goal to respond quickly to a rapidly changing and highly sophisticated consumer landscape (Öberg and Graham 2016). For example, the increasing demand for urban logistics led logistics providers to collaborate with retailers, which is called "re-logistification". Another phenomenon is logistics sprawl i.e. relocation and concentration of logistics facilities towards suburban areas. Multi-floor logistics facilities (i.e. "flexible distribution centers whereby a fleet of mobile warehouses are parked at strategic locations throughout the city" will be utilized (CBRE 2017). Last but not least, there is a trend towards underground cargo transporters (DHL 2012).

In addition, consumption pattern will change due to various trends such as middleclass explosion and on-line shopping that will lead to the growth in the parcel market and in the last-mile delivery and reverse logistics services. These trends already led retailers to insource portions of their logistics function and build their own networks e.g. Amazon (PwC 2011). The recent pandemic also led consumers to panic buying and stockpiling; thus, supply chain managers faced the challenge with regards to demand and stockouts (Hall 2020). Due to the quarantine measures of the coronavirus crisis, several retailers such as Hennes \& Mauritz AB, The Body Shop temporarily closed their physical stores which led online sales to increase. For example, online sales increased 49\% between March 12-April 112020 in the USA; grocery (e.g. Instacart) and electric/electronics retailers are the most important online players while there only a few apparel companies that have been doing well e.g. Lululemon (Popper 
2020). Thus, most of the customers are buing only essential items and according to Foolproof survey, $72 \%$ of adults in the UK supported that had either worn gloves or cleaned a public touch surface and $48 \%$ used contactless payment; thus, this pandemic will change the way that transactions are made and companies should adapt and use mobile payments, QR codes and completely touchless payments (Rigby 2020).

The new business models need to take into consideration the increasing social media engagement e.g. $68 \%$ of millennials tend to buy specific products or services based on friends' social media (Nielsen 2016). Individualization has an impact on the production structures to be more decentralized e.g. healthy lifestyle led to demand for fresh, healthy, unprocessed foods with short shelf life (Mat et al. 2015). Technologies such as 3D printing will enable customers to get involved into the design phase as the customization of the products and services is an added value (Kudus et al. 2016). In the logistics sector, dedicated fleets are used to ensure service requirements are met. In Table 3 seven megatrends and 20 trends identified under the social dimension.

\subsection{Technological}

Under the technological dimension digital transformation has emerged as a key megatrend. Technological advances have increased industrial productivity and there is a rise of new digital industrial technology known as Industry 4.0 which is powered by several technological advances such as big data analytics and robots (Hydrogen Council 2017). It is projected that big data and analytics software sales will grow to $\$ 70$ billion by 2020 and they will be utilized in several industries (IDC 2017). For instance, companies in the pharmaceutical industry can utilize predictive analytics to detect demand spikes, stocks and delivery resources ahead of time (DHL 2017). Within the logistics industry, this trend can be applied for route optimization and real-time tracking of resources (CBRE 2017). Based on the survey from the Business Continuity Institute, most of the companies (59.6\%) utilize big data analytics for their supply chain management to remove silos and enable them to have access to more comprehensive set of data (Business Continuity Institute 2019).

The digital transformation forces companies to rethink what customers value most and adjust operating models to achieve competitive advantages. For example, it is expected that $36 \%$ of financial services firms will make substantial investments in blockchain in the next three years (Harvey 2017). Blockchain can be used in supply chains to avoid paperwork processing in ocean freight, identification of counterfeit products, minimizing the inefficiencies in last-mile deliveries, and tracking of origin (Hackius Petersen 2017; PWC 2019). Regarding the megatrend technology development and automatization, the use of robots in factories and cyber physical systems will affect manufacturing companies in terms of production systems (Leitao et al. 2015). Developments within robotics enable 'reshoring' activities: reintroducing domestic manufacturing to a country. For example, Adidas sportswear manufacturer uses "intelligent robotic technology" and brought parts of their shoe production back to Germany from China. 
Table 3 Social dimension megatrends and trends

\begin{tabular}{|c|c|c|}
\hline Megatrends & Trends & References \\
\hline $\begin{array}{l}\text { Population } \\
\text { growth }\end{array}$ & $\begin{array}{l}\text { Population boom in the } \\
\text { developing countries, growing } \\
\text { demand of resources (e.g. land) }\end{array}$ & $\begin{array}{l}\text { Accenture (2016), Aggelakakis et al. (2015), } \\
\text { Boumphrey and Brehmer (2017), Clausen } \\
\text { et al. (2014), DHL (2013, 2016a), Harrington } \\
\text { (2015), Kwiatkowski and Schäfer (2017), } \\
\text { McKinsey Global Institute (2011), PwC } \\
\text { (2012, 2016b), Roland Berger (2017), United } \\
\text { Nations (2010), UN (2015), van Buren et al. } \\
\text { (2016), Veolia (2016), WEF (2013) }\end{array}$ \\
\hline $\begin{array}{l}\text { Demographic } \\
\text { change }\end{array}$ & $\begin{array}{l}\text { Ageing population boom in } \\
\text { developing countries, young } \\
\text { population boom in developing } \\
\text { countries, migration flows, } \\
\text { labor shortages }\end{array}$ & $\begin{array}{l}\text { Accenture (2016), ALICE (2013), Kearney } \\
\text { AT (2016b), Boston Consulting Group } \\
\text { (2016), Cranfield University (2017), Csiro } \\
\text { (2016), BVL (2013), Deloitte (2017), DHL } \\
\text { (2016b), European Agency for Safety and } \\
\text { Health at Work (2016), Frost and Sullivan } \\
\text { (2017), FTA (2016, 2017), Grant Thornton } \\
\text { (2017), Kewill (2013), KPMG (2016), } \\
\text { McKinsey Global Institute (2011, 2012), } \\
\text { Miebach (2017), PwC (2012, 2015, 2016a), } \\
\text { Roland Berger (2014), Sana (2017), SCM } \\
\text { World (2014), SEMLEP Logistics (2013), } \\
\text { Sikich (2017), SMMT (2015), Veolia (2016), } \\
\text { von der Gracht and Darkow (2011), } \\
\text { Wisskirchen et al. (2017), World Bank Group } \\
\text { (2017) }\end{array}$ \\
\hline Urbanization & Megacities, smart cities & $\begin{array}{l}\text { Accenture (2016), Aggelakakis et al. (2015), } \\
\text { Barclays (2014), Benjelloun et al. (2009), } \\
\text { Bielefeldt et al. (2013), Boumphrey and } \\
\text { Brehmer (2017), CBRE (2016, 2017), } \\
\text { Citylab (2017), Clausen et al. (2014), Csiro } \\
\text { (2014), Deloitte (2017), DHL (2012, 2013, } \\
\text { 2016a, 2017), Elmegaard (2016), European } \\
\text { Agency for Safety and Health at Work } \\
\text { (2016), Gernandt (2012), Grant Thornton } \\
\text { (2017), Harrington (2015), Invata (2017), } \\
\text { ITC (2017), KPMG (2016), Mehmood et al. } \\
\text { (2016), PwC (2009), Schuckmann et al. } \\
\text { (2012), UN (2015), UNIDO (2013, 2016), } \\
\text { United Nations (2010), Veolia (2016), von } \\
\text { der Gracht and Darkow (2016), PLA (2016), } \\
\text { PwC (2015, 2016b), Roland Berger (2017), } \\
\text { World Bank Group (2017), WEF (2013, } \\
\text { 2016) }\end{array}$ \\
\hline
\end{tabular}


Table 3 (continued)

\begin{tabular}{|c|c|c|}
\hline Megatrends & Trends & References \\
\hline $\begin{array}{l}\text { Change in } \\
\text { consumption } \\
\text { pattern }\end{array}$ & $\begin{array}{l}\text { Middle-class explosion, healthy } \\
\text { diets and lifestyles, } \\
\text { consumerism }\end{array}$ & $\begin{array}{l}\text { Kearney AT (2014, 2016a), Barclays (2014), } \\
\text { BVL (2013), Cerasis (2017), Csiro (2014), } \\
\text { Deloitte (2015a, 2017), DHL (2013, 2017), } \\
\text { Gernandt (2012), Horenberg (2016), Kewill } \\
\text { (2013), Lee et al. (2016), PwC (2016c), } \\
\text { Schmidt (2013), van Buren et al. (2016) }\end{array}$ \\
\hline Individualism & $\begin{array}{l}\text { New customer relationship, new } \\
\text { shopping experience, increased } \\
\text { customization }\end{array}$ & $\begin{array}{l}\text { Kearney AT (2016b), Barclays (2014), } \\
\text { Boumphrey and Brehmer (2017), BVL } \\
\text { (2013), CBRE (2016), Cerasis (2017), } \\
\text { Clausen et al. (2014), Csiro (2014, 2016), } \\
\text { Deloitte (2015a, 2017), DHL (2012, 2013, } \\
\text { 2016a), European Commission (2010), EY } \\
\text { (2014, 2016), Gernandt (2012), Infor (2016), } \\
\text { Invata (2017), KPMG (2016), Kwiatkowski } \\
\text { and Schäfer (2017), McKinsey Global } \\
\text { Institute (2012), PwC (2009, 2011, 2015, } \\
\text { 2016a, 2017), Sana (2017), UNIDO (2016), } \\
\text { Veolia (2016), WEF (2016), World Bank } \\
\text { Group (2017) }\end{array}$ \\
\hline Digital natives & $\begin{array}{l}\text { Change of communication } \\
\text { patterns, change of purchasing } \\
\text { patterns, reshaping the } \\
\text { workplace }\end{array}$ & PwC (2016b) \\
\hline $\begin{array}{l}\text { Knowledge } \\
\text { based } \\
\text { economy }\end{array}$ & $\begin{array}{l}\text { Increasing demand for } \\
\text { high-qualification jobs, } \\
\text { emerging skills required, } \\
\text { continuous learning culture }\end{array}$ & $\begin{array}{l}\text { Business Europe (2011), Deloitte (2017), } \\
\text { OECD (2015) }\end{array}$ \\
\hline
\end{tabular}

Apart from robots, additive manufacturing enables easier prototyping and product development and move manufacturing activities closer to the final customers. This technology will reform logistics facilities and the relationships with the suppliers who provide the materials (Chen 2016). It is expected that 3D printing will reach a global value between $\$ 180$ billion and $\$ 490$ billion by 2025 (DHL 2016a). 3D printing will rise competition with e.g. small businesses that are funded through crowdsourcing (Mohr and Khan 2015). This technology will also impact the warehousing industry as along with the servitization some products can be stored digitally thus minimizing the inventory in the warehouses (Horenberg 2016). Regarding distribution, there will be a reduction in shipping, but it is important to highlight that raw materials are still needed (Chen 2016).

Distribution will be also impacted by drones that are expected to be used for quick delivery, thus minimizing the traffic on the roads, internal delivery and for tracking inventory (DHL 2014). Drones can play an important role in intralogistics, e.g. intraplant transport, but there are still issues such as regulations and public concern regarding the unmanned aerial vehicle (DHL 2014). Another important element is the autonomous vessels that can detect and adapt to changing sea and 
weather conditions and avoid collisions (KPMG 2015). There will be only three or four major liner companies, operating either as digitally enabled independents or as small units. Loading, stowage, and sailing will be fully autonomous to unloading directly onto autonomous trains and trucks and drones (McKinsey and Company 2017).

Transport electrification is another megatrend that is influenced by regulations regarding emissions and fuel efficiency. The main impacts on supply chain and logistics industries will be the use of battery electric vehicles, hydrogen fuel cell electric vehicles and hybrid vehicles. It is expected that 1 in 12 cars sold in Japan, California, South Korea and Germany would be powered by hydrogen by 2030 (Hydrogen Council 2017). Recently the UK government has announced $£ 37 \mathrm{~m}$ of investment in developing electric cars, ships, and planes in the UK (UKRI 2020). There is not much availability and choice of electrified transport logistic vehicles in the logistics industry, but new materials lead to reduction in the weight of vehicles thus minimize fuel or electricity consumption (Kleiner et al. 2017). Last, renewable energy sources as a megatrend has several impacts on supply chain and logistics industries e.g. companies such as Apple aim to procure $100 \%$ of their electricity from renewable sources to minimize emissions from supply chain operations) (Apple 2018).

Thus, in Table 4 the four megatrends and 18 trends are presented.

\subsection{Legal}

Consumer protection laws are getting stronger so that consumers can easily return products free of charge or under warranty (Deloitte 2013) and companies have to recall products in case of problems towards customer's safety. These trends impact the return process of supply chain. For instance, Toyota recalled 5.8 million vehicles because of faulty airbags. In addition, there are new EU privacy regulations that aim to protect any personal information. There are different directives regarding consumer protection in the digital market i.e. Directive 2011/83/EU on consumer rights, Directive $95 / 46 / \mathrm{EC}$ on the protection of individuals with regard to the processing and free movement of personal data.

Intellectual property law tries to secure the rights to inventions. However, for companies operating in certain countries such as China, it is challenging and there is a fear of security risks and loss of control when exchanging data (PwC 2016b). New emerging technology such as 3D printing can lead to several issues regarding the intellectual property, too; companies and governments need to solve any legal issue to enable technologies to contribute a large scale of open innovation (Chen 2016).

Thus, data exchange e.g. data regarding inventory, production processes, maintenance and the supply status of products or even financial data is a "big topic" and data sovereignty concepts need to be established for the protection of intellectual property. Data sovereignty is guaranteed by the following three aspects: (1) Data remain decentral and are not integrated in a joint data pool, (2) A precisely graded 
Table 4 Technological dimension megatrends and trends

\begin{tabular}{|c|c|c|}
\hline Megatrends & Trends & References \\
\hline $\begin{array}{l}\text { Digital } \\
\text { transformation }\end{array}$ & $\begin{array}{l}\text { Big data analytics, } \\
\text { artificial } \\
\text { intelligence, } \\
\text { cloud-based } \\
\text { computer systems, } \\
\text { blockchain, Internet } \\
\text { of Things }\end{array}$ & \multirow{2}{*}{$\begin{array}{l}\text { Gernandt (2012), BVL (2013), Clausen et al. (2014), } \\
\text { Hajkowicz et al. (2016), DHL (2016b, 2017), } \\
\text { Harrington (2015), PwC (2009), Schuckmann et al. } \\
\text { (2012), von der Gracht and Darkow (2011), Cerasis } \\
\text { (2017), DHL (2012, 2016a), FTA (2017), Grant } \\
\text { Thornton (2017), PwC (2011, 2016a, 2017), Sana } \\
\text { (2017), Kearney AT (2016a), Boumphrey and } \\
\text { Brehmer (2017), Csiro (2014, 2016), Deloitte (2017), } \\
\text { McKinsey Global Institute (2012, 2016a, 2016b), } \\
\text { UKCES (2014), DHL (2015, 2017), Elmegaard } \\
\text { (2016), European Agency for Safety and Health at } \\
\text { Work (2016), WEF (2016), Kwiatkowski and Schäfer } \\
\text { (2017), UN (2015), Veolia (2016), WEF (2013), } \\
\text { Deloitte (2017), KPMG (2016), Miebach (2017), } \\
\text { SCM World (2014), Sikich (2017), Wisskirchen et al. } \\
\text { (2017), Barclays (2014), Bielefeldt et al. (2013), } \\
\text { CBRE (2017), Mehmood et al. (2016), PLA (2016), } \\
\text { UNIDO (2016), Lee (2016), von der Gracht and } \\
\text { Darkow (2016), PwC (2016a), Schmidt (2013), } \\
\text { Horenberg (2016), European Commission (2010), } \\
\text { Infor (2016), PwC (2017), Boston Consulting Group } \\
\text { (2015), Capgemini (2011), Deloitte (2013, 2016), } \\
\text { EFT (2016), Heijster and Huijbers (2012), Jablonski } \\
\text { (2016), PwC (2016a), Roland Berger (2017), } \\
\text { Technopolis and Fraunhofer (2016), WEF (2017), } \\
\text { Digital map (2017) }\end{array}$} \\
\hline $\begin{array}{l}\text { Technology } \\
\text { development and } \\
\text { automatization }\end{array}$ & $\begin{array}{l}\text { Robots, } \\
\text { cyber-physical } \\
\text { system, augmented } \\
\text { reality and virtual } \\
\text { reality, 3D } \\
\text { printing/additive } \\
\text { manufacturing, } \\
\text { drones, autonomous } \\
\text { systems, automated } \\
\text { guided vehicles, } \\
\text { wearable devices }\end{array}$ & \\
\hline $\begin{array}{l}\text { Electrification of } \\
\text { transport }\end{array}$ & $\begin{array}{l}\text { Battery electric } \\
\text { vehicles, hydrogen } \\
\text { fuel cell electric } \\
\text { vehicles, hybrid } \\
\text { vehicles }\end{array}$ & $\begin{array}{l}\text { FCH (2015), Hydrogen Council (2017), Markets and } \\
\text { Markets (2015), Schorsch (2017), McKinsey (2010), } \\
\text { Kleiner et al. (2017), Speranza (2018), Theverge } \\
\text { (2016), S2R (2017) }\end{array}$ \\
\hline $\begin{array}{l}\text { Renewable } \\
\text { energy sources }\end{array}$ & $\begin{array}{l}\text { Production and } \\
\text { storage of clean } \\
\text { energy and } \\
\text { application to } \\
\text { transportation and } \\
\text { industry, renewable } \\
\text { energy for industrial } \\
\text { processes }\end{array}$ & Hydrogen Council (2017), IGI Global (2017) \\
\hline
\end{tabular}

certification concept and (3) Security of infrastructure through new technological solutions (PwC 2016a). Last but not least, social and environmental regulations aim to achieve sustainable development through its activities on the environment as well as on employees and consumers (Tai and Chuang 2014).

Over the last decade, corporate social responsibility disclosure has increased dramatically. Moreover, vehicle electrification market is driven by stringent emission and fuel efficiency regulations. EU legislation set mandatory emission reduction 
Table 5 Legal dimension megatrends and trends

\begin{tabular}{l|l|l}
\hline Megatrends & Trends & References \\
\hline Consumer protection laws & $\begin{array}{l}\text { Cross-border payments, return } \\
\text { products free of charge or under } \\
\text { warranty, product safety } \\
\text { regulations, privacy }\end{array}$ & Deloitte (2013), Durovic (2019) \\
\hline $\begin{array}{l}\text { Intellectual property law } \\
\text { recial and environmental }\end{array}$ & $\begin{array}{l}\text { Patents, data sovereignty } \\
\text { Corporate social responsibility, } \\
\text { emissions control regulations, } \\
\text { waste and resources } \\
\text { management regulations }\end{array}$ & $\begin{array}{l}\text { Accenture (2016), Aggelakakis } \\
\text { et al. (2015), Kearney AT } \\
\text { (2016b), Citylab (2017), } \\
\text { Deloitte (2013), DHL (2016a, } \\
\text { 2012), ITC (2017), Heijster and } \\
\text { Huijbers (2012), Kewill (2013), } \\
\text { PwC (2011, 2015), van Buren } \\
\text { et al. (2016), Veolia (2016), von } \\
\text { der Gracht and Darkow (2011) }\end{array}$ \\
\hline
\end{tabular}

targets for new cars sold in the EU specifically the fleet average should be 95 grams per kilometer by end of 2020 (Europa 2018). In addition to this, there is a target to reduce the greenhouse gas intensity of fuels by $6 \%$ by 2020 and maritime transport emissions levels at least $40 \%$ by 2030 (IMO 2018). The EU is setting the rules in order to boost resource efficiency and promote recycling e.g. EU's Raw Materials Initiative. These regulations could lead to the relocation of carbon intensive companies and specific industries to regions with not so strict regulations (Ceniga and Sukalovaba 2015). The European Commission recently set a new circular economy action plan. More specifically there is a revision of EU waste legislation that includes new targets and processes to minimize packaging waste (e.g. harmonize separate collection systems), and "mandatory essential requirements" for packaging (i.e. reusable or recyclable) placed on the market (European Commission 2020). The review aims at restricting waste exports that could have harmful impacts in third countries.

Under the legal dimension three megatrends and nine trends emerged (see Table 5).

\subsection{Environmental}

Pollution is a main trend when it comes to climate change. Air pollution, water pollution, and land pollution count to the major types of pollution. Focal firms are responsible for up to $80 \%$ of overall supply chain emissions so they are developing integrated approaches and strategies to minimize carbon emissions (Zimon et al. 2019). For example, Walmart, an American retailer, has launched a program to achieve a reduction of $\mathrm{CO}_{2}$ emissions from its Chinese suppliers by 50 million tons by 2030 (Reuters 2018). Furthermore, accidents, cancelation and delays due to atmospheric changes that are related with the increasing $\mathrm{CO}_{2}$ levels can lead to supply chain network disruptions. As pollution leads to increasing temperatures it 
will impact the transportation and logistics industries due to e.g. asphalt deterioration, buckling of rail lines and damage of the expansion joints on bridges and highways (Schwartz et al. 2014). Packaging will also be in the spotlight over the next five years as fast-tracked deliveries and frequent single-item shipments, create more carbon emissions and packaging waste (DHL 2019).

The depletion of resources such as water, oil (i.e. energy scarcity), and rare earth elements have been highlighted in many studies e.g. Bell et al. (2012). Resource scarcity, the second megatrend, is influenced by the global population, and the increasing demand for resources from consumers, regulations and geopolitical risks (Balatsky et al. 2015; Kalaitzi et al. 2018b). As population grows and the living conditions in developing countries rises along with changing eating habits, more people will require food or develop particular eating habits e.g. more meat, which in turn requires more water and agricultural area.

Specifically, global freshwater withdrawal by the manufacturing industry will grow more than $5 \%$ by 2050 , over a year 2000 baseline, from 245 to 1552 billion $\mathrm{m}^{3}$ (Sachidananda et al. 2016). Companies, particularly the ones for whom water is the primary ingredient in their products, will face disruptions in their operations, e.g. Coca-Cola had to shut down factories in India due to social forces supporting Coca-Cola exploited water resources that were scarce in these regions.

Moreover, land scarcity is a big issue in densely populated cities, and logistics industry solutions have been trying to maximize land productivity e.g. innovative logistics hub construction. For example, a logistic hub will be completed in Singapore in 2019 integrating a multi-level inland container depot, a heavy vehicle park and warehouses (Mizar 2016). Apart from water and land, the energy demand worldwide is forecasted to increase; industrial energy demand will raise by $50 \%$ from 2015 to 2040 and the energy demand for the ships, planes and trains that carry products to factories and to markets will increase by $65 \%$ in the same timeline. Last but not least, rare earth elements scarcity is a crucial issue in manufacturing supply chains. Those elements are used in high technology-based products for different sectors, inter alia defense. China has 35\% of global supply of the rare earth elements (Zhou et al. 2017) and applies tax and export quotas impacting the availability, supply and prices of those resources (Humphries 2003).

Another megatrend that emerged under the environmental dimension is catastrophic events/hazards e.g. flood, drought and pandemic. In particular there are three trends: natural disasters (like hurricanes, volcano eruptions), biological risks (like pandemic) and man-made disasters. Natural disasters can disrupt the supply chains causing interruption in trasportation and production processes: in Europe, recorded losses from climate extremes cost on average EUR 11.6 billion per year between 1980 and 2013 (European Environmental Agency 2017) and damages are projected to increase reaching 32 billion€ per year by $2050\left(\mathrm{COACCH}\right.$ project $\left.2018^{1}\right)$. For example, after the earthbreak in Japan on 2011, the most important car manufacturers froze their production losing US\$72 million a day (Arto et al. 2015); in particular, for

\footnotetext{
${ }^{1}$ https://www.ecologic.eu/sites/files/publication/2018/2811-coacch-review-synthesis-updatedjune-2018.pdf.
} 
several weeks, a shortage of over 150 parts left Toyota's North American operations operating at $30 \%$ of capacity (Canis 2011). Regarding biological risks, it is possible to mention for example the spread of pandemic, supply chains should be mapped and restructured after the outbreak of SARS in 2003 but most of the companies thought that such a disruption is not likely to occur soon again and they were not willing to spend a large amount of labour and time required for these activities (Choi et al. 2020; Simpson 2020). Covid-19 outbreak in 2020 showed the importance of being proactive as this pandemic shut down temporarily factories (e.g. companies from the automotive and apparel industry), and led to traffic/ transportation restriction enforced by quarantine policy. Moreover, some countries enforced a ban to a few product categories e.g. Indonesia and Jordan banned imports of live animals from China and other countries saving vital medical equipment e.g. ventilators, face masks for their own citizens. It is forecasted that Covid-19 outbreak will cost the global economy at least $\$ 1 \operatorname{trn}$ (Simspon 2020). The last trend is related to disasters caused by human behavior; man-made disasters impact on supplier flow, warehousing, distribution and transportation. Ericsson in Spring 2001 lost $\$ 400$ million just because of a fire in a supplier's plant: the gaps of radio-frequency chips were supplied only by that supplier; it took pretty long for Ericsson to get aware of the situation and as a consequence the company had to give up its mobile phone business section (Munim et al. 2015). As consequence of an Explosion at BASF plant in Ludwigshafen in 2016, $15 \%$ of raw materials were missing for the entire supply chain and the production of some products at BASF has been stopped for many weeks (Ivanov 2018).

Under the environmental dimension three megatrends and six trends emerged (see Table 6).

\section{Conclusion}

Megatrends are reshaping society, economies, politics and the environment; so, they can be used to forecast future supply chain developments. There are only a few academic papers and reports that focus on specific megatrends in the field of supply chain management (i.e. Bowersox et al. 2000; Gernandt 2012; Jiang et al. 2017; Mat et al. 2015; Schuckmann et al. 2012; Seppälä 2016; Schmidt 2013; Stank et al. 2015; Sweeney 2013; von der Gracht and Darkow 2011, 2016) and do not provide a comprehensive view on trends and megatrends. This research addresses that gap through an extensive systematic review of the literature. The main contribution of this research is the comprehensive review and assessment of megatrends which was based not only on scientific publications, but also on sectoral studies, and governmental reports while, in addition, further insights have been collected and merged on the megatrends/trends within an interactive session. The need to expand the review and include a variety of publications (e.g. reports by consulting companies) was identified as a research opportunity in the literature review conducted by Malik and Janowska 2018. Based on a systematic literature review and a workshop, a total of 23 megatrends (M) and 72 related trends (T) were identified as the summary in Table 7 
Table 6 Environmental dimension megatrends and trends

\begin{tabular}{|c|c|c|}
\hline Megatrends & Trends & References \\
\hline Climate change & Pollution & $\begin{array}{l}\text { Bielefeldt et al. (2013), Clausen } \\
\text { et al. (2014), DHL (2013, } \\
\text { 2012), FTA (2016), European } \\
\text { Environmental Agency (2012), } \\
\text { Accenture (2016), ITC (2017), } \\
\text { PwC (2015), Mehmood et al. } \\
\text { (2016), PLA (2016), Planning } \\
\text { Institute Australia (2016), PwC } \\
\text { (2009), Roland Berger (2016), } \\
\text { Schwartz et al. (2014), United } \\
\text { Nations (2015, 2010), UNIDO } \\
\text { (2013), WEF (2013) }\end{array}$ \\
\hline Resource scarcity & $\begin{array}{l}\text { Lack of resources such as water, } \\
\text { land, energy, food and rare earth } \\
\text { elements, waste increase }\end{array}$ & $\begin{array}{l}\text { Accenture (2016), Aggelakakis } \\
\text { et al. (2015), ALICE (2013), } \\
\text { Kearney AT (2014, 2016a), } \\
\text { Barclays (2014), Boumphrey } \\
\text { and Brehmer (2017), CBRE } \\
\text { (2016), Cerasis (2017), Clausen } \\
\text { et al. (2014), Csiro (2014), } \\
\text { Csiro (2016), Deloitte (2013), } \\
\text { DHL (2012, 2015, 2016a), } \\
\text { European Commission (2010), } \\
\text { Harrington (2015), Frost and } \\
\text { Sullivan (2017), FTA (2016), } \\
\text { Industry Innovation council } \\
\text { (2011), Invata (2017), Kewill } \\
\text { (2013), KPMG (2016), PLA } \\
\text { (2016), Planning Institute } \\
\text { Australia (2016), PwC (2009, } \\
\text { 2011, 2015, 2016b), Roland } \\
\text { Berger (2016), Schuckmann } \\
\text { et al. (2012), United Nations } \\
\text { (2010), van Buren et al. (2016), } \\
\text { Veolia (2016), von der Gracht } \\
\text { and Darkow (2011, 2016), WEF } \\
\text { (2013, 2016) }\end{array}$ \\
\hline Catastrophic events/hazards & $\begin{array}{l}\text { Natural disaster, biological risks } \\
\text { (e.g. pandemic),man-made } \\
\text { disasters }\end{array}$ & $\begin{array}{l}\text { Doherty and Botwright (2020), } \\
\text { FTA (2020), Rogers and Oak } \\
(2020) \text {, Simpson (2020) }\end{array}$ \\
\hline
\end{tabular}

shows. To our knowledge this is the first published comprehensive literature review on megatrends and trends in the field of supply chain management.

The identified megatrends (e.g. globalization) could help managers and researchers alike to consider impacts on product, process and supply chain configuration. In particular, the study provides to managers in a systematic way megatrends and trends that are critical for the generation of future industrial scenarios and could offer a starting point to customise specific long-term strategies for their company. 
Table 7 Overall megatrends and trends identified

\begin{tabular}{|c|c|c|}
\hline Dimensions & Megatrends & Trends \\
\hline \multirow[t]{8}{*}{ Political } & \multirow[t]{4}{*}{ Protectionism } & Import tariffs \\
\hline & & Quotas \\
\hline & & Different tax structures \\
\hline & & Subsidies \\
\hline & \multirow[t]{2}{*}{ Political stability } & Terrorism/conflict \\
\hline & & Social unrest \\
\hline & \multirow[t]{2}{*}{ Supranationalism } & Trade agreements \\
\hline & & Free movement \\
\hline \multirow[t]{11}{*}{ Economic } & \multirow[t]{6}{*}{ Global trade shift } & Economic growth in emerging economies \\
\hline & & Export growth \\
\hline & & Investment \\
\hline & & Globalization \\
\hline & & Glocalization \\
\hline & & Emergence of born-global firms \\
\hline & \multirow[t]{2}{*}{ Digital economy } & Sharing economy \\
\hline & & $\begin{array}{l}\text { From an economy of goods to an } \\
\text { economy of services }\end{array}$ \\
\hline & \multirow[t]{3}{*}{ Financial innovation } & Digital currencies \\
\hline & & Cashless payment \\
\hline & & $\begin{array}{l}\text { The financial technologies (Fintech) } \\
\text { revolution }\end{array}$ \\
\hline \multirow[t]{13}{*}{ Social } & \multirow[t]{2}{*}{ Population growth } & $\begin{array}{l}\text { Population boom in the developing } \\
\text { countries }\end{array}$ \\
\hline & & Growing demand of resources (e.g. land) \\
\hline & \multirow[t]{4}{*}{ Demographic change } & $\begin{array}{l}\text { Ageing population boom in developing } \\
\text { countries }\end{array}$ \\
\hline & & $\begin{array}{l}\text { Young population boom in developing } \\
\text { countries }\end{array}$ \\
\hline & & Migration flows \\
\hline & & Labor shortages \\
\hline & \multirow[t]{2}{*}{ Urbanization } & Megacities \\
\hline & & Smart cities \\
\hline & \multirow[t]{3}{*}{ Change in consumption pattern } & Middle-class explosion \\
\hline & & Healthy diets and lifestyles \\
\hline & & Consumerism \\
\hline & \multirow[t]{2}{*}{ Individualism } & New customer relationship \\
\hline & & New shopping experience \\
\hline
\end{tabular}


Table 7 (continued)

\begin{tabular}{|c|c|c|}
\hline Dimensions & Megatrends & Trends \\
\hline & & Increase customization \\
\hline & \multirow[t]{3}{*}{ Digital natives } & Change of communication patterns \\
\hline & & Change of purchasing patterns \\
\hline & & Reshaping the workplace \\
\hline & \multirow[t]{3}{*}{ Knowledge based economy } & $\begin{array}{l}\text { Increase demand for high-qualification } \\
\text { jobs }\end{array}$ \\
\hline & & Emerging skills required \\
\hline & & Continuous learning culture \\
\hline \multirow[t]{18}{*}{ Technological } & \multirow[t]{5}{*}{ Digital transformation } & Big data analytics \\
\hline & & Artificial intelligence \\
\hline & & Cloud based computer systems \\
\hline & & Blockchain \\
\hline & & Internet of Things \\
\hline & \multirow{8}{*}{$\begin{array}{l}\text { Technology development and } \\
\text { automatization }\end{array}$} & Robots \\
\hline & & Cyber-physical system \\
\hline & & Augmented reality and virtual reality \\
\hline & & 3D printing/additive manufacturing \\
\hline & & Drones \\
\hline & & Autonomous systems \\
\hline & & Automated guided vehicles \\
\hline & & Wearable devices \\
\hline & \multirow[t]{3}{*}{ Electrification of transport } & Battery electric vehicles \\
\hline & & Hydrogen fuel cell electric vehicles \\
\hline & & Hybrid vehicles \\
\hline & \multirow[t]{2}{*}{ Renewable energy sources } & $\begin{array}{l}\text { Production and storage of clean energy } \\
\text { and application to transportation and } \\
\text { industry }\end{array}$ \\
\hline & & Renewable energy for industrial processes \\
\hline \multirow[t]{8}{*}{ Legal } & \multirow[t]{4}{*}{ Consumer protection laws } & Cross-border payments \\
\hline & & $\begin{array}{l}\text { Return products free of charge or under } \\
\text { warranty }\end{array}$ \\
\hline & & Product safety regulations \\
\hline & & Privacy \\
\hline & \multirow[t]{2}{*}{ Intellectual property law } & Patents \\
\hline & & Data sovereignty \\
\hline & \multirow{2}{*}{$\begin{array}{l}\text { Social and environmental } \\
\text { regulations }\end{array}$} & Corporate social responsibility \\
\hline & & Emissions control regulations \\
\hline
\end{tabular}


Table 7 (continued)

\begin{tabular}{l|l|l}
\hline Dimensions & Megatrends & Trends \\
\hline \multirow{2}{*}{ Environmental } & Climate change & $\begin{array}{l}\text { Waste and resources management } \\
\text { regulations }\end{array}$ \\
\cline { 2 - 3 } & Resource scarcity & Pollution \\
\cline { 2 - 3 } & Catastrophic events/hazards & $\begin{array}{l}\text { Lack of resources such as water, land, } \\
\text { energy, food and rare earth elements }\end{array}$ \\
\cline { 3 - 3 } & Waste increase \\
\cline { 2 - 3 } & & Natural disaster \\
\cline { 3 - 3 } & Biological risks (e.g. pandemic \\
\cline { 3 - 3 } & Man-made disasters \\
\hline
\end{tabular}

This chapter gives a glimpse into the opportunities and challenges that supply chain managers may face in the future; thus, they can develop an early warning system and develop as well as contingency plans. It provides an opportunity to prepare and respond to a broad range of potential disruptions in the future and to create more resilient and interactive supply chains. Based on these results, it is possible to formulate scenarios that describe the evolution and the implications of the identified megatrends and trends on supply chains for the next decade. Although the paper highlights some of the interesting insights in the SCL literature, there are a few limitations of the paper. Future research can consider other megatrends/trends given the dynamic, complex and fast evolving nature of modern supply chains.

Acknowledgements We are grateful to all contributors of the Next-Net project team and particularly to Kerley Pires, Irene Marchiori, Ricardo Zimmermann and the experts participating in the workshop. This work was financially supported by the European Union's Horizon 2020 Research and Innovation Program under the Grant Agreement No. 768884.

\section{References}

Accenture (2016) New realities, new opportunities. https://www.accenture.com/ae-en/ /media/ Accenture/Conversion-Assets/DotCom/Documents/Global/PDF/Industries_5/Accenture-Cha nging-Client-Advisor-Relationship.pdf. Accessed 17 Oct 2017

Aggelakakis A, Bernandino J, Boile M, Christidis P, Condeco A, Krail P, Papanikolaou A, Reichenbach M, Schippl J (2015) The future of the transport industry. http://publications.jrc.ec. europa.eu/repository/bitstream/JRC93544/future\%20of\%20tansport\%20industry\%20report\% 20final3.pdf. Accessed 17 Oct 2017

ALICE (2013) Sustainable, safe and secure supply chain, research \& innovation roadmap. https:// www.etp-logistics.eu/wp-content/uploads/2015/07/W16mayo-kopie.pdf. Accessed 17 Oct 2017

Arto I, Andreoni V, Rueda Cantuche JM (2015) Global impacts of the automotive supply chain disruption following the Japanese earthquake of 2011. Econ Syst Res 27(3):306-323

Balatsky A, Balatsky G, Borysov S (2015) Resource demand growth and sustainability due to increased world consumption. Sustainability 7:3430-3440 
Barbieri P, Ellram L, Formentini M Ries J (2019) Supply chain governance in the age of digital transformation. https://www.emeraldgrouppublishing.com/products/journals/call_for_ papers.htm?id=8747. Accessed 29 Nov 2019

Barclays (2014) The last mile exploring the online purchasing and delivery journey. https://www. home.barclays/content/dam/barclayspublic/docs/BarclaysNews/2014/September/the-last-milereport.pdf. Accessed 17 Oct 2017

Bell J, Autry C, Mollenkopf D, Thornton L (2012) A natural resource scarcity typology: theoretical foundations and strategic implications for supply chain management. J Bus Logist 33:158-166

Benjelloun A, Crainic TG, Brigras Y (2009) Toward a taxonomy of city logistics projects. CIRRELT, Quebec, Canada

Bielefeldt C, Bak M, Borkowski P, Carreno M, Matthews B, Stewart K, Caramanico G, Cooper J, Enei R, Biosca O, Shibayama T, de Stasio C, Schnell O (2013) COMPASS-final results and conclusions, Deliverable 2.1 of COMPASS, Co-funded by FP7. TRI, Edinburgh Napier University, Edinburgh, November 2013

Birkel H, Hartmann E (2019) Impact of IoT challenges and risks for SCM. Supply Chain Manag 24:39-61

Bons RWH, Alt R, Lee HG, Weber B (2012) Banking in the Internet and mobile era. Electron Markets 22:197-202

Boston Consulting Group (2015) Time to accelerate in the race toward industry $4.0 \mathrm{https}$ ://www.zvw. de/media.media.72e472fb-1698-4a15-8858-344351c8902f.original.pdf. Accessed 2 Jan 2018

Boston Consulting Group (2016) Time to accelerate in the race toward industry 4.0. https://www.bcgperspectives.com/content/articles/lean-manufacturing-operations-time-acc elerate-race-toward-industry-4/ Accessed 2 Jan 2018

Boston Consulting Group (2017) Global payments 2017. http://image-src.bcg.com/Images/BCGGlobal-Payments-2017-Oct-2017_tcm9-173047.pdf. Accessed 6 Jan 2018

Boumphrey S, Brehmer Z (2017) Megatrend analysis: putting the consumers at the heart of the business. http://go.euromonitor.com/white-paper-2017-megatrend-analysis.html?utm_campaign= WP-170905-Megatrend-Analysis\&utm_medium=Blog\&utm_source=Blog\&lipi=urn\%3Ali\% 3Apage\%3Ad_flagship3_pulse_read\%3BbmOvuBXHSK6qyPvuYdl3RQ\%3D\%3D. Accessed 3 Jan 2017

Bowersox DJ, Closs DJ, Stank TP (2000) Ten mega-trends that will revolutionize supply chain logistics. J Bus Logist 21:1-16

Bueno-Solano A, Cedillo-Campos MG (2014) Dynamic impact on global supply chains performance of disruptions propagation produced by terrorist acts. Transp Res Part E 61:1-12

Business Continuity Institute (2019) Supply chain resilience report 2019. https://insider.zurich. co.uk/app/uploads/2019/11/BCISupplyChainResilienceReportOctober2019SingleLow1.pdf. Accessed 25 Mar 2020

Business Europe (2011) Plugging the skills gap the clock is ticking. https://www.businesseurope. eu/sites/buseur/files/media/imported/2011-00855-E.pdf. Accessed 12 Dec 2017

BVL (2013) Trends and strategies in logistics and supply chain management. https://www.bvl.de/ misc/filePush.php\%3Fid\%3D21777+\&cd=5\&hl=en\&ct=clnk\&gl=uk. Accessed 17 Oct 2017

Calatayud A, Mangan J, Christopher M (2019) The self-thinking supply chain. Supply Chain Manag 24:22-38

Caniato F, Henke M, Zsidisin GA (2019) Supply chain finance: historical foundations, current research, future developments. J Purch Supply Manag 25:99-104

Canis B (2011) Motor vehicle supply chain: effects of the Japanese earthquake and tsunami. Diane Publishing

Capgemini (2011) Digital transformation: a roadmap for billion-dollar organizations. https://www. capgemini.com/wp-content/uploads/2017/07/Digital_Transformation_A_Road-Map_for_Bil lion-Dollar_Organizations.pdf. Accessed 2 Jan 2018

Capgemini (2017) World payments report 2017. https://www.worldpaymentsreport.com/download. Accessed 6 Jan 2018 
CBRE (2016) Last mile city logistics, global industrial and logistics. http://www.colliers.com/ en-gb/-/media/Files/EMEA/emea/research/industrial-and-logistics/ColliersFromFirstMiletoL astMileGlobalLogisticsEuropean\%20Version. Accessed 17 Oct 2017

CBRE (2017) Last milelcity logistics 2017. https://www.cbre.com/research-and-reports/Global-Ind ustrial-and-Logistics-Last-Mile-City-Logistics-January-2017. Accessed 17 Oct 2017

Ceniga P, Sukalovaba V (2015) Future of logistics management in the process of globalization. Procedia Econ Finance 26:160-166

Cerasis (2017) The most impactful supply chain \& logistics trends in 2017. http://cerasis.com/wpcontent/uploads/2017/02/The-Most-Impactful-Supply-Chain_Logistics-Trends-in-2017-eBook. pdf. Accessed 17 Oct 2017

Chen Z (2016) Research on the impact of 3d printing on the international supply chain https://www. hindawi.com/journals/amse/2016/4173873/. Accessed 17 Oct 2017

Choi T, Rogers T, Vakil B (2020) Coronavirus is a wake-up call for supply chain management. https://hbr.org/2020/03/coronavirus-is-a-wake-up-call-for-supply-chain-management. Accessed 30 May 2020

Citylab (2017) European commission innovation and networks executive agency horizon 2020 programme for research and innovation, reducing impacts and costs of freight and service trips in urban areas. http://www.citylab-project.eu/deliverables/D3_3.pdf. Accessed 17 Oct 2017

Clausen U, Holloh, KD. Kadow M (2014) Visions of the future: transportation and logistics 2030, examining the potential for the development of road and rail transportation to 2030. https://www.dbschenker.cz/file/log-cz-en/8323784/LMGHMkq3TcObfsii-DB2 LUw5VFk/7923390/data/Visions_of_the_Future_2030.pdf. Accessed 17 Oct 2017

Collis J, Hussey R (2009) Business research: a practical guide for undergraduate \& postgraduate students, 3rd edn. Palgrave Macmillan, London

Cranfield University (2017) UK manufacturing skills shortages, leadership and investment. https:// www.cranfield.ac.uk/ /media/files/nmd-2017-white-paper.ashx. Accessed 6 Jan 2018

Csiro (2014) The emerging Asian middle class and opportunities for Australian manufacturing. https://www.researchgate.net/publication/314179371_Make_for_Asia_the_emerging_Asian_ middle_class_and_opportunities_for_Australian_manufacturing. Accessed 6 Jan 2018

Csiro (2016) Megatrends and scenarios for jobs and employment in Australia over the coming twenty years https://publications.csiro.au/rpr/download?pid=csiro:EP161054\&dsid=DS1. Accessed 6 Jan 2018

de Kluyver C (2010) Fundamentals of global strategy: a business model approach. Business Expert Press, Harvard, New York, N.Y.

Deloitte (2013) A wave of digital change Trends in digital E-nnovation 2013. https://www2.del oitte.com/au/en/pages/about-deloitte/articles/pl-digital-trends.html. Accessed 2 Jan 2018

Deloitte (2015a) Making it personal - One in three consumers wants personalised products. https:// www2.deloitte.com/uk/en/pages/press-releases/articles/one-in-three-consumers-wants-person alised-products.html. Accessed 31 Oct 2017

Deloitte (2015b) MHI Annual Industry Report, Supply chain innovation-making the impossible possible. https://www2.deloitte.com/content/dam/Deloitte/dk/Documents/process-and-ope rations/2015\%20MHI\%20Industry\%20Report.pdf. Accessed 2 Jan 2018

Deloitte (2016) Tech trends 2016 innovating in the digital era. https://www2.deloitte.com/content/ dam/Deloitte/global/Documents/Technology/gx-tech-trends-2016-innovating-digital-era.pdf. Accessed 2 Jan 2018

Deloitte (2017) The 2017 MHI annual industry report next-generation supply chains: digital, on-demand and always-on. https://static1.squarespace.com/static/562164dae4b0099ac9c04b5c/ t/595126ece4fcb533d1d7fe2d/1498490608835/Nextgen+-+MHI+2017+Industry+Report.pdf. Accessed 2 Jan 2018

Denyer D, Tranfield D (2009) Producing a systematic review. In: Buchanan DA, Bryman A (eds) The SAGE handbook of organizational research methods. Sage Publications Ltd. London, pp 671-689 
DHL (2012) Delivering tomorrow Logistics 2050 — a scenario study. http://www.dhl.com/content/ dam/Local_Images/g0/aboutus/SpecialInterest/Logistics2050/szenario_study_logistics_2050. pdf. Accessed 31 Oct 2017

DHL (2013) Low-cost sensor technology, A DHL perspective on implications and use cases for the logistics industry. https://delivering-tomorrow.com/wp-content/uploads/2015/08/CSI_Stu die_Low_Sensor.pdf. Accessed 31 Oct 2017

DHL (2014) Augmented reality in logistics, changing the way we see logistics-a DHL perspective. http://www.dhl.com/content/dam/downloads/g0/about_us/logistics_insights/ csi_augmented_reality_report_290414.pdf. Accessed 2 Jan 2018

DHL (2015) Internet of things in logistics, a collaborative report by DHL and Cisco on implications and use cases for the logistics industry 2015. https://www.dpdhl.com/content/dam/dpdhl/presse/ pdf/2015/DHLTrendReport_Internet_of_things.pdf. Accessed 2 Jan 2018

DHL (2016a) logistics trend radar Delivering insight today. Creating value tomorrow. http://www. dhl.com/content/dam/downloads/g0/about_us/logistics_insights/dhl_logistics_trend_radar_ 2016.pdf. Accessed 31 Oct 2017

DHL (2016b) Robotics in logistics, A DPDHL perspective on implications and use cases for the logistics industry. http://www.dhl.com/content/dam/downloads/g0/about_us/logistics_insights/ dhl_trendreport_robotics.pdf. Accessed 6 Jan 2018

DHL (2017) The future of life sciences and healthcare logistics. A DHL perspective on key trends and technologies. http://www.dhl.com/content/dam/downloads/g0/about_us/logistics_ins ights/dhl_future_of_lsh_2017.pdf. Accessed 31 Oct 2017

DHL (2019) Rethinking packaging A DHL perspective on the future of packaging in the logistics industry. https://www.dhl.com/content/dam/dhl/global/core/documents/pdf/glo-core-rethinkingpackaging-trend-report.pdf. Accessed 25 Mar 2020

Digital map (2017). Be decisive: a guide to smart decision-making using parcel boundary data. https://www.digmap.com/whitepaper/smart-decision-parcel-boundary-data/. Accessed 31 Oct 2017

Doherty S and Botwright K (2020) What past disruptions can teach us about reviving supply chains after COVID-19 https://www.weforum.org/agenda/2020/03/covid-19-coronavirus-lessons-pastsupply-chain-disruptions/. Accessed 11 June 2020

Durovic M (2019) International consumer law: what is it all about? J Consum Policy 43:125-143

Elmegaard H (2016) How to deal with new trends in retail logistics best practices for thriving in a rapidly changing environment. http://www.damco.com/ /media/files/oldsite/download-centre/ white-papers/eguide-trends-in-retail-logistics.pdf. Accessed 31 Oct 2017

Europa (2015) Trade in goods and customs duties in TTIP. http://trade.ec.europa.eu/doclib/docs/ 2015/january/tradoc_152998.1\%20Trade\%20in\%20goods\%20and\%20customs\%20tariffs.pdf. Accessed 23 Jan 2017

Europa (2018) Reducing $\mathrm{CO}_{2}$ emissions from passenger cars-before 2020. https://ec.europa.eu/ clima/policies/transport/vehicles/cars_en. Accessed 11 June 2020

European Agency for Safety and Health at Work (2016) Key trends and drivers of change in information and communication technologies and work location, Foresight on new and emerging risks in OSH working report. https://osha.europa.eu/en/tools-and-publications/publications/keytrends-and-drivers-change-information-and-communication Accessed 31 October 2017

European Environmental Agency (2012) Climate Change, impacts and vulnerability in Europe. https://www.eea.europa.eu/publications/climate-impacts-and-vulnerability-2012. Accessed 10 Jan 2018

European Environmental Agency (2017) Economic losses from climate-related extremes in Europe. https://www.eea.europa.eu/data-and-maps/indicators/direct-losses-from-weather-disast ers-3/assessment-2. Accessed 10 Jan 2018

European Commission (2010) Factories of the future PPP strategic multi-annual roadmap prepared by the Ad-hoc Industrial Advisory Group. https://ec.europa.eu/research/industrial_technologies/ pdf/ppp-factories-of-the-future-strategic-multiannual-roadmap-info-day_en.pdf. Accessed 31 October 2017 
European Commission (2020) Circular Economy action plan for a cleaner and more competitive Europe. https://ec.europa.eu/environment/circular-economy/pdf/new_circular_economy_a ction_plan.pdf Accessed 12 Mar 2020

EvaluatePharma (2012) Biotech and Pharma 2012 year in review. http://info.evaluatepharma.com/ rs/evaluatepharmaltd/images/EPV_Review_2012.pdf. Accessed 31 Oct 2017

EY (2014) Macro-economic impacts of the low carbon transition. https://europeanclimate.org/wpcontent/uploads/2014/06/EY_ECF_Macro-economicimpacts-of-the-low-carbon-transition_R eport_2014-06-05.pdf. Accessed 31 Oct 2017

EY (2016) The upside of disruption megatrends shaping 2016 and beyond. https://cdn.ey.com/ echannel/gl/en/issues/business-environment/2016megatrends/001-056_EY_Megatrends_report. pdf. Accessed 31 Oct 2017

EY (2017) EY FinTech Adoption Index 2017: the rapid emergence of FinTech https://cdn.ey.com/ echannel/gl/en/issues/business-environment/2016megatrends/001-056_EY_Megatrends_report. pdf. Accessed 31 Oct 2017

Fawcett SE, Waller MA (2014) Supply chain game changers-mega, nano, and virtual trends—and forces that impede supply chain design (i.e., building a winning team). J Bus Logist 35:157-164

FCH JU (2015) Urban buses: alternative powertrains for Europe. http://www.gppq.fct.pt/h2020/ docs/brochuras/fch-ju/20121029\%20urban\%20buses, \%20alternative\%20powertrains $\% 20$ for $\%$ 20europe\%20-\%20final\%20report_0.pdf. Accessed 17 Nov 2017

Francesco S, Ardita T (2015) Markets' globalization and emerging economies. The MINTs economic growth: developments and prospects. Int J Bus Commer 5:38-55

Frost and Sullivan (2017) Manufacturing 4.0: a playbook for navigating the journey to IT modernization and transformation. http://nala.frost.com/forms/itmodernization. Accessed 3 Nov 2017

FTA (2016) Logistics report 2016. http://www.fta.co.uk/export/sites/fta/_galleries/downloads/log istics_report/lr16-web-030616.pdf. Accessed 31 Oct 2017

FTA (2017) Logistics report 2017. http://www.fta.co.uk/export/sites/fta/_t/2017/logistics-report2017.pdf. Accessed 31 Oct 2017

FTA (2019) HGV driver shortage climbs to 59,000. https://fta.co.uk/media/press-releases/2019/oct ober-2019/hgv-driver-shortage-climbs-to-59-000 Accessed 25 Mar 2020

FTA (2020) Coronavirus: dealing with supply chain disruption. https://www.fticonsulting.com/ /media/Files/apac-files/insights/reports/2020/mar/coronavirus-supply-chain-disruption.pdf. Accessed 30 May 2020

Gernandt K (2012) Megatrends and their impact on logistics. http://www.tliap.nus.edu.sg/pdf/ whitepapers/12_Nov_SCI05_Megatrends_and_\%20their\%20impact\%20on\%20Logistics.pdf. Accessed 27 Oct 2017

Grant Thornton (2017) The future of growth and the manufacturing industry: disrupting products, production and supply. https://www.grantthornton.com/ /media/content-page-files/campai gns/growth/pdfs/2017/Future-Growth-Manufacturing-report. Accessed 2 Jan 2018

Hackius Petersen (2017) Blockchain in logistics and supply chain: trick or treat? https://tubdok.tub. tuhh.de/bitstream/11420/1447/1/petersen_hackius_blockchain_in_scm_and_logistics_hicl_2 017.pdf. Accessed 31 Oct 2017

Hajkowicz S, Reeson A, Rudd L, Bratanova A, Hodgers L, Mason C, Boughen N (2016) Tomorrow's digitally enabled workforce. https://www.acs.org.au/content/dam/acs/acs-documents/16-0026_D ATA61_REPORT_TomorrowsDigiallyEnabledWorkforce_WEB_160128.pdf. Accessed 2 Jan 2018

Hall M (2020) Millions of pounds worth of panic buying food heading in the bin. https://www.businesswaste.co.uk/millions-of-pounds-worth-of-panic-buying-food-headingin-the-bin/. Accessed 25 Mar 2020

Harrington D (2015) From first mile to last mile global industrial \& logistics trends. http://www. colliers.com/en-gb/-/media/Files/EMEA/emea/research/industrial-and-logistics/ColliersFrom FirstMiletoLastMileGlobalLogisticsEuropean\%20Version. Accessed 31 Oct 2017 
Harvey C (2017) Blockchain's future: nine predictions. https://www.datamation.com/applications/ blockchains-future-nine-predictions.html. Accessed 25 Oct 2017

Heijster J, Huijbers S (2012) Future of automotive manufacturing trends and developments within the automotive production. http://www.acemr.eu/uploads/media/Trendstudy_ACEMR_Manufac turing_01.pdf. Accessed 2 Jan 2018

Heiko A, von der Gracht, Darkow I-L (2016) Energy-constrained and low-carbon scenarios for the transportation and logistics industry. Int J Logistics Manage 27(1):142-166

Hill J (2017) Europe is providing more than $€ 112$ billion annually in fossil fuel subsidies. https://cleantechnica.com/2017/09/29/europe-providing-e112-billion-annually-fossil-fuelsubsidies/. Accessed 14 Dec 2017

Hong PYP, Song IH (2010) Glocalization of social work practice. Global and local responses to globalization, International Social Work 53:656-670

Horenberg (2016). Applications within Logistics 4.0 A research conducted on the visions of 3PL service providers. http://essay.utwente.n1/72668/1/Horenberg_BA_BMS.pdf. Accessed 31 Oct 2017

Humphries A (2003) Sustained monopolistic business relationships: a UK defence procurement case. Cranfield university school of management PhD thesis academic year 2002/2003

Hydrogen Council (2017) Hydrogen scaling up: a sustainable pathway for the global energy transition. http://hydrogencouncil.com/wp-content/uploads/2017/11/Hydrogen-scaling-up-HydrogenCouncil.pdf. Accessed 2 Jan 2018

IDC (2017) Big data and business analytics western european revenues forecast to reach $\$ 34.1$ billion this year, led by banking and manufacturing investments. https://www.idc.com/getdoc. jsp?containerId=prEMEA42433217. Accessed 31 Oct 2017

IGI Global (2017) What is technological development. https://www.igiglobal.com/dictionary/tec hnological-development/48985. Accessed 31 Oct 2017

IMO (2018) Greenhouse Gas Emissions http://www.imo.org/en/OurWork/Environment/Pollution Prevention/AirPollution/Pages/GHG-Emissions.aspx. Accessed 31 Oct 2017

Infor (2016) Meet the factory of the future, where information technology (IT) and operational technology (OT) converge. https://www.infor.com/content/executive-briefs/meet-the-factory-ofthe-future.pdf/. Accessed 31 Oct 2017

Invata (2017) Intralogistics. http://www.invata.com/intralogistics-4-0/. Accessed 31 Oct 2017

ITC (2017) How can we improve urban freight distribution in the UK? Challenges and solutions. http://www.theitc.org.uk/wp-content/uploads/2017/05/ITC-Urban-Distributionreport-May-2017.pdf. Accessed 31 Oct 2017

Ivanov D (2018) Structural dynamics and resilience in supply chain risk management, vol 265. Springer International Publishing, Berlin, Germany

Jablonski C (2016) Navigating the technological disruption of shipping \& logistics. http://downlo ads.tradeshift.com/Technological\%20Disruption.pdf. Accessed 2 Jan 2018

Jiang R, Kleer R, Piller FT (2017) Predicting the future of additive manufacturing: a Delphi study on economic and societal implications of 3D printing for 2030. Technol Forecast Soc Chang 117:84-97

Kalaitzi D, Matopoulos A, Marchiori I, Muerza V, Pires K, Sardesai S (2018a) Megatrends shaping the future of the supply chain and logistics, forthcoming in proceedings (CD) of the 23rd annual conference logistics research network annual conference, 5-7 September, Plymouth, UK

Kalaitzi D, Matopoulos A, Bourlakis M, Tate W (2018b) Supply chain strategies in an era of natural resource scarcity. Int J Oper Prod Manag 38:784-809

Kearney AT (2014) Rethinking supply in food and beverage. https://www.atkearney.com/docume nts/10192/5304443/Rethinking+Supply+in+Food+and+Beverage.pdf/. Accessed 17 Oct 2017

Kearney AT (2016a) From globalization to islandization. https://www.atkearney.com/web/globalbusiness-policy-council/article?/a/from-globalization-to-islandization. Accessed 3 Jan 2017

Kearney AT (2016b) Global retail expansion at a crossroads. https://www.atkearney.com/docume nts/10192/8226719/Global+Retail+Expansion+at+a+Crossroads\%E2\%80\%932016+GRDI.pdf/ dc845ffc-fe28-4623-bdd4-b36f3a443787. Accessed 21 Nov 2017 
Kemppainen K, Vepsäläinen A (2003) Trends in industrial supply chains and networks. Int J Phys Distrib Logistics Manag 33:709-719

Kewill (2013) White paper: logistics in 2020: the future is closer than you think. http://info.kewill. $\mathrm{com} / \mathrm{rs} /$ kewill/images/Kewill\%20Whitepaper\%20\%20Logistics\%20in\%202020\%20-\%20The\% 20Future\%20is\%20Closer\%20Than\%20You\%20Think.pdf?mkt_tok=3RkMMJWWfF9wsRo nsqnAZKXonjHpfsX56e4vW6SzlMI\%2F0ER3fOvrPUfGjI4ASMVkI\%2BSLDwEYGJlv6Sg FTLnDMbB63rgJXBc\%3D. Accessed 31 Oct 2017

Kleiner Perkins (2017) Media = distribution disruption. https://f.hypotheses.org/wp-content/blogs. dir/903/files/2017/09/InternetTrends2017Report_Extrait.pdf. Accessed 12 Jan 2018

Kleiner F, Beermann M, Çatay B, Beers E, Davies H, Taeck Lim O (2017) Current status of the electrification of transport logistic vehicles-early niche markets and commercialization opportunities. https://pure.coventry.ac.uk/ws/portalfiles/portal/11131568. Accessed 31 Oct 2017

Kotler P (2002) Marketing management—analysis, planning, implementation, and control, 9th edn. Prentice-Hall, Englewood Cliffs

KPMG (2014) The UK Automotive Industry and the EU. https://www.smmt.co.uk/wp-content/upl oads/sites/2/SMMT-KPMG-EU-Report.pdf. Accessed 10 Dec 2017

KPMG (2015) Connected and autonomous vehicles-opportunity the UK economic. https:// assets.kpmg.com/content/dam/kpmg/images/2015/05/connected-and-autonomous-vehicles.pdf. Accessed 31 Oct 2017

KPMG (2016) E-commerce retail logistics in India May 2018 driving the change. https://assets. $\mathrm{kpmg} / \mathrm{content} / \mathrm{dam} / \mathrm{kpmg} / \mathrm{in} / \mathrm{pdf} / 2018 / 05 / \mathrm{e}$-commerce-retail-logistics.pdf. Accessed 14 Jan 2018

KPMG (2017) Brexit basics the four freedoms. https://assets.kpmg.com/content/dam/kpmg/xx/pdf/ 2017/02/brexit-basics-the-four-freedoms.pdf. Accessed 10 Dec 2017

Kudus A, Campbell R, Bibb R, (2016) Assessing the value of 3D printed personalised products. In: International conference on mass customization and personalization in Central Europe, Novi Sad, Serbia, 21-23 September

Kwiatkowski M, Schäfer C (2017) Fruit trade 2025. Ideas-impulses-insights. http://agricultura. gencat.cat/web/.content/de_departament/de02_estadistiques_observatoris/27_butlletins/02_but lletins_nd/documents_nd/fitxers_estatics_nd/2017/0194_2017_SProductius_FruitaHorta_Fru ita-Prospectiva-2025.pdf. Accessed 6 Jan 2018

Lee, H, Chen Y, Gillai B, Rammohan S (2016) Technological disruption and innovation in last-mile delivery, Stanford value chain innovation initiative in collaboration with united states postal service office of inspector general, gsb.stanford.edu/r/vcii, white paperl June 2016. https://www.gsb.stanford.edu/sites/gsb/files/publication-pdf/vcii-publication technologicaldisruption-innovation-last-mile-delivery.pdf. Accessed 6 Jan 2018

Leitao P, Colombo AW, Karnouskos S (2015) Industrial automation based on cyber-physical systems technologies: prototype implementations and challenges. Comput Indu 81:11-25

Malik R, Janowska A (2018) Megatrends and their use in economic analyses of contemporary challenges in the world economy. Res Pap Wrocław Univ Econ 523:209-220

Markets and Markets (2015) Vehicle electrification market worth 92.59 billion USD by 2022. https:// www.marketsandmarkets.com/PressReleases/vehicle-electrification.asp. Accessed 14 Jan 2018

Mat N, Cerceau J, Shi L, Park H-S, Junqua G, Lopez-Ferber M (2015) Socioecological transitions toward low-carbon port cities: trends, changes and adaptation processes in Asia and Europe. $\mathrm{J}$ Cleaner Prod 1:1-14

McKevitt J (2017) UK, European suppliers consider cutting ties due to Brexit. https://www.supply chaindive.com/news/Brexit-supply-chain-effects-CIPS-survey/442752/. Accessed 31 Oct 2017

McKinsey Global Institute (2011) Urban world: cities and the rise of the consuming class. https:// www.mckinsey.com/ /media/McKinsey/Featured\%20Insights/Urbanization/Urban\%20world\% 20Cities\%20and $\% 20$ the $\% 20$ rise $\% 20$ of $\% 20$ the $\% 20$ consuming $\% 20$ class/MGI_Urban_world_ Rise_of_the_consuming_class_Full_report.ashx. Accessed 31 Oct 2017

McKinsey Global Institute (2012) manufacturing the future: the next era of global growth and innovation. https://www.mckinsey.com/ /media/McKinsey/Business\%20Functions/Operations/ 
Our\%20Insights/The $\% 20$ future $\% 20$ of $\% 20$ manufacturing/MGI_\%20Manufacturing_Full\%20r eport_Nov\%202012.ashx. Accessed 31 Oct 2017

McKinsey Global Institute (2016a) Digital globalization: the new era of global flows. https://www. mckinsey.com/business-functions/digital-mckinsey/our-insights/digital-globalization-the-newera-of-global-flows. Accessed 31 Oct 2017

McKinsey Global Institute (2016b) Automotive revolution-perspective towards 2030. How the convergence of disruptive technology-driven trends could transform the auto industry. https://www.mckinsey.com/industries/automotive-and-assembly/our-insights/dis ruptive-trends-that-will-transform-the-auto-industry. Accessed 31 Oct 2017

Mehmood Y, Marwat S, Kuladinithi K, Förster A, Zaki Y, Görg C, Timm-Giel A (2016) M2M Potentials in logistics and transportation industry. Logist. Res. 1:9-15

McKinsey (2010) A portfolio of power-trains for Europe: a fact-based analysis-the role of battery electric vehicles, Plug-in hybrids and fuel cell electric vehicles. Fuel cell. http://www.zeroemiss ionvehicles.eu/. Accessed 25 Nov 2017

McKinsey and Company (2017) Container shipping: the next 50 years. https://www.safety4sea. com/wp-content/uploads/2017/10/McKinsey-Container-shipping-The-next-50-years-2017_10. pdf. Accessed 2 Jan 2018

MHI (2020) The $2020 \mathrm{MHI}$ annual industry report—embracing the Digital Mindset. https://www. mhi.org/publications/report. Accessed 25 Mar 2020

Miebach (2017) Robots in picking logistics, a statement from the perspective of Dr. Frank Hohenstein and Ole Wagner, Miebach Consulting. http://www.miebach.com/fileadmin/user_u pload/DynamicContent/Publication/Downloads/2017/Miebach_Whitepaper_Robotik_2017-03/ Miebach_Whitepaper_Robotic_eng_Screen_ES.pdf. Accessed 6 Jan 2018

Mizar SP (2016) Logistics players innovate to beat land scarcity. https://www.singaporebus iness.com/2016/logistics-players-innovate-to-beat-land-scarcity.html?subFormJan2018=visible. Accessed 11 June 2018

Munim ZH, Azmat M, Dorfer B (2015) Impact of man-made disasters on commercial logistics. Int J Econom Commerce Manage 3(6):128-138

Mohr S, Khan O (2015) 3D printing and its disruptive impacts on supply chains of the future. Technol Innov Manag Rev 5:20-25

Munim ZH, Azmat M, Dorfer B (2015) Impact of man-made disasters on commercial logistics. Int J Econom Commerce Manage 3(6):128-138

Nielsen (2016) Global connected commerce: is e-tail therapy the new retail therapy? https://www. nielsen.com/content/dam/nielsenglobal/jp/docs/report/2016/Nielsen-Global-Connected-Com merce-Report-January-2016. Accessed 6 Jan 2018

Öberg C, Graham G (2016) How smart cities will change supply chain management: a technical viewpoint. Prod Plan Control 6:529-538

OECD (2015) The future of productivity: main background papers skill mismatch and public policy in OECD countries. https://www.oecd.org/eco/growth/Skill-mismatch-and-public-policyin-OECD-countries.pdf. Accessed 12 Dec 2017

Paez A (2017) Gray literature: an important resource in systematic reviews. J Evid Based Med $10: 233-240$

Pictet asset management (2017) What are megatrends? https://www.am.pictet/en/netherlands/art icles/2017/megatrends/what-are-megatrends. Accessed 2 Jan 2018

PLA (2016) Through the lens: megatrends shaping our future. https://www.planning.org.au/docume nts/item/7504. Accessed 17 Oct 2017

Planning Institute Australia (2016) Through the lens: megatrends shaping our future. https://www. planning.org.au/documents/item/7504. Accessed 25 Oct 2017

Popper N (2020) Americans keep clicking to buy, minting new online shopping winners. https://www.nytimes.com/interactive/2020/05/13/technology/online-shopping-buyingsales-coronavirus.html. Accessed 30 May 2020 
PwC_-Price Waterhouse Coopers (2009) Transportation \& logistics 2030 series: How will supply chains evolve in an energy-constrained, low-carbon world? https://www.pwc.com/gx/en/indust ries/transportation-logistics/publications/t12030/tl2030-pub.html. Accessed 31 Oct 2017

PwC-Price Waterhouse Coopers (2011) Pharma 2020: supplying the future which path will you take? https://www.pwc.ch/en/publications/2016/pharma-2020-supplying-the-future.pdf. Accessed 25 Oct 2017

PwC (2012) Transportation and logistics 2030 Volume 5: winning the talent race. https://www.pwc. com/gx/en/transportation-logistics/pdf/pwc-tl-2030-volume-5.pdf. Accessed 6 Jan 2018

PwC (2015) Money is no object: understanding the evolving cryptocurrency market. https:// www.pwc.com/us/en/financial-services/publications/assets/pwc-cryptocurrency-evolution.pdf. Accessed 20 Jan 2018

PwC (2016a) Industry 4.0: building the digital enterprise transportation and logistics key findings. https://www.pwc.com/gx/en/industries/transportation-logistics/publications/transp ortation-logistics-key-findings.html. Accessed 6 Jan 2018

PwC (2016b) Five megatrends and their implications for global defense and security. https://www. pwc.com/gx/en/government-public-services/assets/five-megatrends-implications.pdf. Accessed 25 Oct 2017

PwC (2016c) Healthy eating is increasingly on consumer's agendas, with millennials leading the way. http://pwc.blogs.com/press_room/2016/08/healthy-eating-is-increasingly-on-consum ers-agendas-with-millennials-leading-the-way.html. Accessed 6 Jan 2018

PWC (2019) Transportation and logistics trends 2019. https://www.pwc.com/cl/es/publicaciones/ assets/2019/Transportatio-and-logistics-trends-pwc-2019.pdf. Accessed 25 Mar 2020

PwC-Price Waterhouse Coopers (2017) Industrial manufacturing trends. https://www.strategyand. pwc.com/trend/2017-industrial-manufacturing-trends. Accessed 25 Oct 2017

Reuters (2018) Walmart urges China suppliers to cut $\mathrm{CO}_{2}$ by 50 million tonnes by 2030. https://www.reuters.com/article/us-walmart-china-carbon/walmart-urges-china-suppliersto-cut-co2-by-50-million-tons-by-2020-idUSKBN1H50HV. Accessed 20 Nov 2017

Rigby C (2020) How Covid-19 is changing the way shoppers buy: three studies. https://internetr etailing.net/covid-19/covid-19/how-covid-19-is-changing-the-way-shoppers-buy-three-studies21348. Accessed 31 May 2020

Rogers C, Oak E (2020) Long road to recovery: coronavirus lessons from supply chain and financial data. https://www.spglobal.com/marketintelligence/en/documents/long-road-to-recovery-corona virus-lessons-from-supply-chain-and-financial-data.pdf. Accessed 30 May 2020

Roland Berger (2014) Roland berger trend compendium 2030. Trend 2 Globalization Future Markets. https://www.rolandberger.com/en/Publications/pub_trend_compendium_2030_megatr end_2_globalization_future_markets.html. Accessed 25 Oct 2017

Roland Berger (2016) Trend 3: scarcity of resources. https://www.rolandberger.com/en/Publicati ons/pub_trend_compendium_2030_megatrend_3_scarcity_of_resources.html. Accessed 17 Nov 2017

Roland Berger (2017) Megatrend 1 demographic dynamics. Roland Berger Trend Compendium 2030 https://www.rolandberger.com/en/Publications/pub_trend_compendium_2030_megatr end_1_demographic_dynamics.html. Accessed 17 Nov 2017

S2R JU (2017) Shift to rail joint undertaking. https://shift2rail.org. Accessed 25 Nov 2017

Sachidananda M, Webb P, Rahimifard S (2016) A concept of water usage efficiency to support water reduction in manufacturing industry. Sustainability 8:1222

Sana (2017) Manufacturing industry report: mastering industry 4.0 with E-Commerce. https://www. hso.com/fileadmin/user_upload/sana-ebook-manufacturing-uk_2_.pdf. Accessed 25 Oct 2017

Schorsch R (2017) Regulation and electrification in vehicle sales forecast scenarios how will forecasts reflect disruptive trends? http://cdn.ihs.com/www/pdf/20170228-EngSchorsch.pdf. Accessed 14 Jan 2018

Schuckmann S, Gnatzy T, Darkow I, von der Gracht H (2012) Technol Forecast Soc Change 79:1373-1387 
Schmidt F (2013) Supply chain trends impacting the air cargo industry, assessing trends and their impacts in three industry sectors. https://repository.tudelft.nl/islandora/object/uuid:a268ac47cac6-4e33-88c8-e0c32cbfe90d?collection=education. Accessed 6 Jan 2018

Schwartz HG, Meyer M, Burbank CJ, Kuby M, Oster C, Posey J, Russo EJ,Rypinski A (2014) Ch. 5: transportation. Climate change impacts in the United States: The third national climate assessment. Melillo JM, Terese TC, Richmond, Yohe GW (eds) U.S. Global Change Research Program, pp 130-149

SCM World (2014) The future of manufacturing maximum flexibility at competitive prices. http://scnavigator.avnet.com/wp-content/uploads/2014/12/The-Future-ofManufacturingMaximum-Flexibility-at-Competitive-Prices.pdf. Accessed 25 Oct 2017

SEMLEP Logistics (2013) Logistics report. http://www.semlep.com/resources/uploads/SEMLEP LOGISTICS_REPORT_2013_final.pdf. Accessed 25 Oct 2017

Seppälä M (2016) Logistics megatrends and their potential effects on demand for logistics premises in Finland. https://pdfs.semanticscholar.org/2c32/2968a1a867cb3a8d28fa1aa766f4d3 88911b.pdf. Accessed 2 Jan 2018

Shang C, Chaloupka F, Fong G, Thompson M, O'Connor R (2015) The association between tax structure and cigarette price variability: findings from the ITC Project. https://pdfs.semanticscho lar.org/822f/38f057b465e8145ade89108e67efd3bdab63.pdf. Accessed 3 Jan 2017

Sikich (2017) Manufacturing report trends and strategies to help manufacturers understand growth challenges and capture opportunities. https://leaglobal.com/thought_leadership/2017sikichma nufacturingreport.pdf. Accessed 6 Jan 2018

Simpson P (2020) Coronavirus and the end of the global supply chain. https://www.cips.org/supplymanagement/analysis/2020/april/the-end-of-the-global-supply-chain/. Accessed 30 May 2020

SMMT (2015) The future of UK automotive manufacturing in 2025 and beyond. http://www. apcuk.co.uk/wp-content/uploads/2015/09/AutoAnalysis-report-the-future-of-UK-automotivemanufactuing-October-2015.pdf. Accessed 25 Oct 2017

Speranza M (2018) Trends in transportation and logistics. Eur J Oper Res 264:830-836

Stank T, Autry C, Daugherty P, Closs D (2015) Reimagining the 10 megatrends that will revolutionize supply chain logistics. Transp J 54:7-32

Sweeney E (2013, Spring) Supply chain 'mega-trends': current status and future trends. J Chartered Inst Logistics Transp (CILT) 1:31-34

Tai F, Chuang S (2014) Corporate social responsibility. iBusiness 6:117-130

Technopolis and Fraunhofer (2016) Regional Innovation Monitor Plus 2016 Thematic Paper 3Industry 4.0, Advanced Materials (Nanotechnology)

The Conference Board of Canada (2013) Understanding the truck driver supply and demand gap and its implications for the Canadian economy. http://www.drivershortage.ca/wp-content/ uploads/2013/03/Understanding-the-Truck-Driver-Supply-and-Demand-Gap1.pdf. Accessed 25 Oct 2017

Theverge (2016) Alstom Coradia Ilint -hydrogen train. https://www.theverge.com/2016/9/23/130 22400/hydrogen-train-germany-coradia-ilint alstominnotrans. Accessed 24 Nov 2017

UKCES (2014) The future of work: jobs and skills in 2030. https://assets.publishing.service.gov. uk/government/uploads/system/uploads/attachment_data/file/303334/er84-the-future-of-workevidence-report.pdf. Accessed 25 Oct 2017

UKRI (2020) Key investment to create pioneering centres for electrification of transport. https://www.ukri.org/news/key-investment-to-create-pioneering-centres-of-excellence-forelectrification-of-transport/. Accessed 25 Mar 2020

UNIDO (2013) Emerging trends in global advanced manufacturing: challenges, opportunities and policy responses policy. https://www.unido.org/fileadmin/user_media/Services/PSD/Emerging _ Trends_UNIDO_2013.PDF. Accessed 31 Oct 2017

UNIDO (2016) Emerging trends in global advanced manufacturing: challenges, opportunities and policy responses. https://institute.unido.org/wp-content/uploads/2017/06/emerging_trends_ global_manufacturing.pdf. Accessed 31 Oct 2017 
United Nations (2010) Trends in sustainable development economic \& social affairs towards sustainable consumption and production. https://sustainabledevelopment.un.org/content/docume nts/15Trends_in_sustainable_consumption_and_production.pdf. Accessed 31 Oct 2017

United Nations (2014) World urbanization prospects. https://esa.un.org/unpd/wup/publications/ files/wup2014-highlights.pdf. Accessed 12 Dec 2017

United Nations (2015) 70th session of the general assembly United Nations summit on sustainable development 2015 informal summary 25-27 September 2015. United Nations Headquarters, New York

van Buren N, Demmers M, van der Heijden R, Witlox F (2016) Towards a circular economy: the role of Dutch logistics industries and governments. Sustainability 8:647

Veolia (2016) Imagine 2050 The future of water, waste and energy: how UK industry will need to adapt for tomorrow. https://www.veolia.co.uk/imagine-industry-2050. Accessed 3 Nov 2017

von der Gracht H, Darkow I (2011) Improving FTA through methodological innovation, crossvalidation, and scientific foundation-the case of FUTURE OF LOGISTICS 2025. In: The 4th international Seville conference on future-oriented technology analysis (FTA): 12 and 13 May 2011

Wang Y, Han J, Beynon-Davies P (2019) Understanding blockchain technology for future supply chains: a systematic literature review and research agenda. Supply Chain Manag 24:62-84

WEF (2013) Outlook on the logistics \& supply chain industry 2013. http://www3.weforum.org/ docs/WEF_GAC_LogisticsSupplyChainSystems_Outlook_2013.pdf. Accessed 3 Nov 2017

WEF (2016) Digital transformation of industries logistics industry. http://reports.weforum.org/ digital-transformation/wp-content/blogs.dir/94/mp/files/pages/files/dti-logistics-industry-whitepaper.pdf. Accessed 31 Oct 2017

WEFORUM (2016) The free movement of people: what it is and why it matters. https://www.wef orum.org/agenda/2016/09/free-movement-of-people-explainer/. Accessed 10 Dec 2017

WEF (2017) Technology and Innovation for the Future of Production: accelerating value creation. http://www3.weforum.org/docs/WEF_White_Paper_Technology_Innovation_Future_ of_Production_2017.pdf. Accessed 31 Oct 2017

Wisskirchen G, Biacabe B, Bormann U, Muntz A, Niehaus G, Soler G, von Brauchitsch B (2017) Artificial intelligence and robotics and their impact on the workplace. https://www.ibanet.org/ Document/Default.aspx?DocumentUid=c06aa1a3-d355-4866-beda-9a3a8779ba6e. Accessed 6 Jan 2018

World economic forum (2016) The world's free trade areas-and all you need to know about them. https://www.weforum.org/agenda/2016/05/world-free-trade-areas-everything-youneed-to-know/. Accessed 10 Dec 2017

World Bank Group (2017) Trouble in the making? The future of manufacturing-led development. https://openknowledge.worldbank.org/bitstream/handle/10986/27946/9781464811746. pdf. Accessed 25 Oct 2017

Yudha W, Tjahjono B (2019). Stakeholder mapping and analysis of the renewable energy industry in Indonesia. Energies 12:602

Zhou B, Li Z, Chen C (2017) Global potential of rare earth resources and rare earth demand from clean technologies. Minerals 7:1-14

Zimon D, Tyan J, Sroufe R (2019) Implementing sustainable supply chain management: reactive, cooperative, and dynamic models. Sustainability 11(24):7227-7249 
Open Access This chapter is licensed under the terms of the Creative Commons Attribution 4.0 International License (http://creativecommons.org/licenses/by/4.0/), which permits use, sharing, adaptation, distribution and reproduction in any medium or format, as long as you give appropriate credit to the original author(s) and the source, provide a link to the Creative Commons license and indicate if changes were made.

The images or other third party material in this chapter are included in the chapter's Creative Commons license, unless indicated otherwise in a credit line to the material. If material is not included in the chapter's Creative Commons license and your intended use is not permitted by statutory regulation or exceeds the permitted use, you will need to obtain permission directly from the copyright holder.

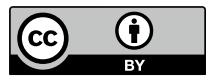

